\title{
Seasonal variations in spatial usage by the estuarine dolphin, Sotalia guianensis (van Bénéden, 1864) (Cetacea; Delphinidae) at its southern limit of distribution
}

\author{
Wedekin, LL.*, Daura-Jorge, FG., Piacentini, VQ. and Simões-Lopes, PC. \\ Laboratório de Mamíferos Aquáticos, Departamento de Ecologia e Zoologia, CCB, Universidade Federal de Santa Catarina, \\ Campus Universitário, s/n, CEP 88040-900, Florianópolis, SC, Brazil \\ *e-mail: lwedekin@ hotmail.com
}

Received August 24, 2004 - Accepted March 14, 2005 - Distributed February 28, 2007

(With 4 figures)

\begin{abstract}
The use of space by the resident population of estuarine dolphins (Sotalia guianensis) in Norte Bay, southern Brazil was studied by boat surveys between 2000 and 2003. Data such as the geographical position and group size was collected at 5-minute intervals using focal-group sampling. The distribution and seasonal and daily group home-ranges were estimated using a GIS (Geographic Information System) environment. The dolphins did not use the area homogeneously, restricting their activities to a well-defined area located in the western part of the bay, while the use of the eastern part was not observed. A discrepancy between the Environment Protection Area of Anhatomirim, created especially to protect this population and the distribution of the dolphins was observed. Seasonal group home-range varied both qualitatively and quantitatively among the four consecutive seasons analyzed. The dolphins tended to use a larger area in cold seasons, when apparently the abundance of major prey items is lower. Core areas of intense use were identified, and also varied seasonally. These core areas may be regarded as critical habitats and require special legislation and control. The mean daily group home-range did not differ statistically among seasons. The present study corroborates a spatially strict residency pattern of the estuarine dolphin in highly productive coastal ecosystems.
\end{abstract}

Keywords: distribution, home-range, seasonality, Cetacea, Norte Bay.

\section{Variação sazonal no uso espacial pelo boto-cinza, Sotalia guianensis (Cetacea; Delphinidae) no seu limite sul de distribuição}

\section{Resumo}

A utilização espacial pela população residente de botos-cinza, Sotalia guianensis, na Baía Norte de Santa Catarina, Sul do Brasil, foi estudada por meio de saídas de barco realizadas entre 2000 e 2003. Dados como posição geográfica (GPS) e tamanho de grupo foram obtidos utilizando-se o método de grupo focal. A distribuição e a área de vida diária e sazonal do grupo foram estimadas por um SIG (Sistema de Informações Geográficas). O uso do espaço pelos botos foi heterogêneo, restringindo suas atividades a uma área bem definida, localizada na parte oeste da baía, enquanto a utilização do lado leste não foi observada. Observou-se uma discrepância entre a distribuição dos botos e a Área de Proteção Ambiental de Anhatomirim, criada especialmente para proteger esta população. A área de vida sazonal do grupo variou tanto qualitativamente como quantitativamente nas quatro estações do ano consecutivas estudadas. Os botos tenderam a utilizar uma área maior nas estações frias do ano, quando a abundância de suas presas potenciais parece ser menor. Identificaram-se áreas de maior concentração de indivíduos, que também tiveram variação sazonal. Estas áreas de concentração podem ser consideradas hábitats críticos e exigem controle e legislação especial. Não houve uma diferença sazonal significativa nas áreas de vida diária do grupo de botos nas diferentes estações do ano estudadas. Os resultados deste trabalho apontam para um padrão de residência espacialmente restrita de $S$. guianensis em ecossistemas costeiros de grande produtividade.

Palavras-chave: distribuição, área de vida, sazonalidade, Cetacea, Baía Norte.

\section{Introduction}

Two basic forms of describing a species' use of space are the distribution and the home-range. Distribution can be defined as the "occurrence and spatial arrangement of a species within a defined area at a particular time" (Thompson et al., 1998). Burt (1943) defines home-range as "the area traversed by the individual in its normal ac- 
tivities of food gathering, mating, and caring for young". Distribution is a level of analysis which focuses on the entire species or population, while the analysis of homerange focuses on the individual or social group level.

The estuarine dolphin, Sotalia guianensis (according to Monteiro-Filho et al., 2002), is a small cetacean species that can be found in estuaries, protected bays and coastal waters along the western Atlantic Ocean coast from Honduras (Silva and Best, 1996) to Norte Bay, southern Brazil (Simões-Lopes, 1988). At Norte Bay there is a resident population of estuarine dolphins with a high degree of site fidelity and residency (Flores, 1999, 2003). Based on the highest number of individuals observed in one day, the population of estuarine dolphins of Norte Bay comprise at least 60 individuals (Daura-Jorge, 2003), but this population size is probably underestimated. The bottlenose dolphin (Tursiops truncatus) can also be observed in the coastal waters of Norte Bay (Flores, 2003; Wedekin et al., 2004).

The estuarine dolphin is classified as "data deficient" by the IUCN Red Data Book (IBAMA/GTEMA, 2001). In spite of this status, the ecological and social-economic importance of the southernmost population, and the great anthropogenic pressure that it suffers, demands conservation efforts in the area (Wedekin, 2003). This situation led to the creation of the Environmental Protection Area (EPA) of Anhatomirim in 1992 with the purpose of protecting the estuarine dolphin population of Norte Bay.

Various authors have described seasonal changes in the use of space by coastal cetacean species (e.g. Shane, 1980; Würsig and Würsig, 1980; Irvine et al., 1981; Nichol and Shackleton, 1996; Wilson et al., 1997; Karczmarski et al., 1999; Bejder and Dawson, 2001). Despite this, not much literature is available concerning the estuarine dolphin's use of space, and seasonal changes have never before been recorded.

In the present work, we analyze the spatial distribution and the variation of seasonal and daily home-ranges of the resident group of estuarine dolphins at the southernmost occurrence point of the species, the Norte Bay, southern Brazil.

\section{Material and Methods}

\subsection{Study area}

The Norte Bay is one of the two protected coastal bays that separate the mainland and the Island of Santa Catarina in southern Brazil $\left(27^{\circ} 30^{\prime} \mathrm{S}\right.$ and $48^{\circ} 32^{\prime} \mathrm{W}$, Figure 1). It covers an area of approximately $250 \mathrm{~km}^{2}$.

The hydrological features of Norte bay are very similar to those of the adjacent open waters, which have a strong seasonal variation of oceanographic characteristics (Cerutti, 1996). The water temperature varies markedly between cold and hot seasons, ranging from $29^{\circ} \mathrm{C}$ to a minimum of $15{ }^{\circ} \mathrm{C}$ (Cerutti, 1996). The water circulation inside the bay is highly influenced by the wind and tide currents (Filho et al., 1997). The mean depth of the bay is 3.5 metres $( \pm 2.37$ metres), with deeper waters in

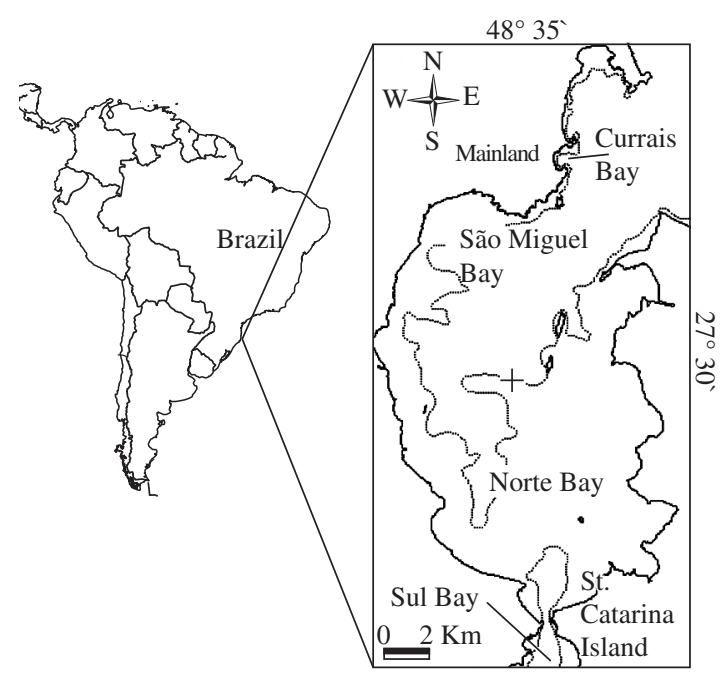

Figure 1. Geographic location of Norte Bay and estuarine dolphin study area in southern Brazil. Dotted lines show 3 meter isobath.

both south and north channels (22 and 11 metres, respectively). The margins of the bay consist of a mosaic of sand beaches, rocky shores and mangroves, the latter of which contributes to the marine productivity of the area.

The Norte Bay is highly modified and influenced by human activities posing threats to marine life such as physical alteration and pollution. There are almost half a million people in the surrounding land of the Norte Bay, and this land is experiencing a rapid process of urban expansion (Cerutti, 1996).

\subsection{Boat survey procedure}

Systematic one-day research cruises were conducted aboard a 5-m sailing boat (with a 5-hp outboard motor). The boat followed a fixed circular route, leaving from the eastern part of the bay and running counterclockwise until a dolphin group was encountered. In order to sample the study area homogeneously, additional research cruises with alternative routes were also carried out. The group was followed for the longest possible time during a one-day period using focal-group sampling (Lehner, 1996). Sometimes the first encountered group was arbitrarily left and the boat continued to sample the area. This last procedure was also conducted to reduce any bias due to an unequal sampling effort. During the observation of a group of dolphins, experienced observers scored group size, behaviour, geographical positions and other information at 5-min intervals (= record). Whenever there were bad weather conditions (sea state over Beaufort 4 and rain) the surveys were stopped.

The basic social unit considered in the present study was the group. A group was interpreted as any aggregation of dolphins observed in apparent association, and often, but not always, engaged in the same activity, where it was generally possible to directly count the individuals (adapted from Shane, 1990). In practice, the 
studied groups had a very dynamic organization and smaller social units (called subgroups), generally consisting of two to seven individuals and characterized by a distance among individuals of less than the equivalent of two body sizes, could also be identified, but they were considered to be part of the group.

\subsection{Data analysis}

A nautical chart of Norte Bay was digitized and all geographic locations were entered into a GIS database using Microsoft ${ }^{\circledR}$ Office Excel and ESRI ArcView ${ }^{\circledR}$ 3.1. software. A distribution map was made using the geographical positions of all systematic survey records ( $\mathrm{n}=2.373)$, strandings from 1989 to $2002(\mathrm{n}=37)$ and opportunistic sightings made by experienced observers $(n=4)$.

Some evidence, provided by extensive scientific research, suggests that the estuarine dolphin population of Norte Bay rarely disperses or separates, acting as a socially-cohesive unit. This evidence includes: extensive overlapping among individual home-ranges (Flores, 2003), a high degree of site fidelity and residency (Flores, 1999, 2003), and group sizes larger than observed for most other areas where this species can be found (DauraJorge, 2003). Moreover, two different groups are rarely observed on the same day, and when two groups were observed, they were never more than $1 \mathrm{~km}$ apart from each other (Daura-Jorge, 2003). For this reason, even considering that occasional large-scale individual movements and dispersal may occur, the group home-range concept was applied in the present study in the same way as it is applied in some primate social group studies (e.g. Stacey, 1986; Passamani and Rylands, 2000; Castro, 2003).

The group home-range was calculated using the ArcView extension called "The Animal Movement Analyst Extension - AMAE" (Hooge and Eichenlaub, 1997). The fixed kernel $95 \%$ and the minimum convex polygon methods were used for group home-range estimation, and fixed kernel $50 \%$ was used for core area estimation (for the description of the methods and assumptions, see Harris et al., 1990; Powell, 2000). Group home-range data was sorted by season in a consecutive one-year period of systematic data collection and similar field efforts (Table 1). Whenever there was an overlap of the home-range estimates with land, the area of terres- trial habitat was subtracted from the final estimate.

The assumption of the kernel method that spatial autocorrelated data may cause bias in home-range estimation (Swihart and Slade, 1985; Harris et al., 1990) was not considered, since recent findings have shown that the violation of this assumption does not produce any biologically relevant distortion in the estimation (Reynolds and Laundre, 1990; Solla et al., 1999).

The fixed kernel smoothing parameter $(h)$ was calculated by AMAE extension using the least square crossvalidation procedure (Worton, 1989).

The minimum convex polygon home-range size was plotted against the number of records for each season (see Harris et al., 1990). Using this procedure, whenever the curve stabilizes, or reaches an asymptote, the sample size (or number of records) is sufficient.

Daily home-range was calculated through the minimum convex polygon method and the mean value of each season was also calculated. Differences among seasons were tested by Kruskal-Wallis analysis of variance (Siegel, 1956) with Statistica 5.0 software. Due to the unequal sample sizes among daily home-range estimates, a Pearson correlation (Siegel, 1956) was used to test the influence of the sample size on the daily homerange size with the Statistica program.

\section{Results}

\subsection{Field effort}

The systematic surveys were conducted from September 2000 to October 2003, and 197 hours (out of $422 \mathrm{~h}$ of effort) were of direct observation of dolphin groups. Dolphins were not observed on $29 \%$ of the oneday surveys. The mean direct observation time for the same group of dolphins during one day was 4.31 hours (range $=0.56$ to 8.08 hours). The range size vs. number of sightings curves reached an asymptote for all seasons analyzed, indicating that the sample size was sufficient for the seasonal group home-range estimates.

\subsection{Distribution}

Estuarine dolphins did not use the area homogeneously and were observed in a well-defined $50 \mathrm{~km}^{2}$ area on the west (mainland) side of Norte Bay along a $24 \mathrm{~km}$ north-south stretch of coast (Figure 2). The southernmost

Table 1. Field effort and direct observation of the distribution and seasonal home-range estimates.

\begin{tabular}{lcccc}
\hline & $\begin{array}{c}\text { Number of positions/ } \\
\text { days }\end{array}$ & $\begin{array}{c}\text { Field effort } \\
\text { (hours) }\end{array}$ & $\begin{array}{c}\text { Direct observation } \\
\text { (hours) }\end{array}$ & $\begin{array}{c}\text { Observation/effort } \\
* \mathbf{1 0 0}\end{array}$ \\
\hline $\begin{array}{c}\text { Distribution } \\
\text { (May 2000 to October 2003) }\end{array}$ & $2.373 / 69$ & 422.50 & 197.75 & 46.80 \\
Seasonal group home-range & & & & \\
$\quad$ Spring 2001 & $334 / 9$ & 60.91 & 27.83 & 45.69 \\
$\quad$ Summer 2002 & $367 / 10$ & 53.33 & 30.58 & 57.34 \\
$\quad$ Autumn 2002 & $302 / 9$ & 51.66 & 25.16 & 48.70 \\
Winter 2002 & $309 / 9$ & 36.83 & 25.75 & 69.91 \\
\hline
\end{tabular}


occurrence point for the species was located in Sul Bay, suggesting that the resident group sporadically crosses the narrow and deep channel that separates Norte and Sul Bays. The presence of estuarine dolphins in the eastern (island) part of Norte Bay, or movements in and out of the bay, were never observed. This fact does not indicate that these movements or the use of the eastern part of Norte Bay are not possible, but suggests that the frequency of these events is probably rare. Only about $29 \%$ of the distribution of the dolphins detected in the present study was inside the Environment Protection Area of Anhatomirim. Strandings occurred all along the Norte Bay coastal line and were not restricted to the borders near the distribution of the dolphins.

\subsection{Seasonal group home-range}

Each season, dolphins tended to restrict their activities to specific areas (seasonal group home-range), which varied qualitatively and quantitatively. Inside the seasonal dolphin group home-range, core areas of intense use could

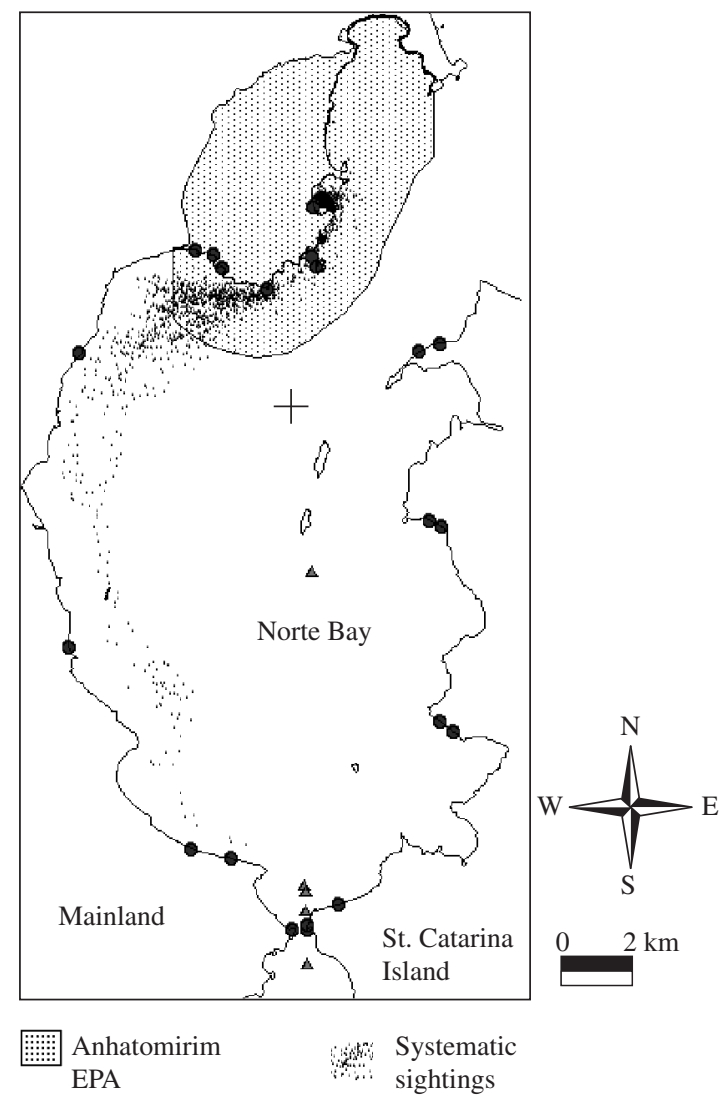

Strandings

Opportunistic
sightings

$$
\begin{aligned}
& \text { UTM reference point: } \\
& 740000-6960000
\end{aligned}
$$

Figure 2. Distribution of Sotalia guianensis sightings and strandings in Norte Bay. be identified, and these areas also varied throughout the four different seasons analyzed (Figure 3; Table 2).

The dolphins used similar areas in spring 2001 and summer 2002, which had only one core area (Currais Bay) and the smallest group home-range size (kernel 95\%: 8.32 and $8.42 \mathrm{~km}^{2}$ respectively). The group homerange was considerably larger in autumn, 2002 (kernel 95\%: $20.27 \mathrm{~km}^{2}$ ) and two distinct core areas could be identified (Currais and São Miguel Bays). Finally, winter, 2002 was characterized by only one core area (São Miguel Bay), distinct from the spring, 2001 and summer, 2002 core area, and by having the largest group homerange size (kernel 95\%: $32.12 \mathrm{~km}^{2}$ ). Besides the seasonal spatial use variation, there was a trend towards greater spatial requirements in autumn, 2002 and winter, 2002 in contrast with spring, 2001 and summer, 2002.

\subsection{Daily group home-range}

There was no correlation between the daily direct observation time and the size of the daily home-range estimate (Pearson correlation $=0.133 ; \mathrm{p}=0.4462$ ) . Since daily sample sizes did not influence the daily home-range estimates, a seasonal comparison could be made with this spatial parameter. The mean daily homerange estimates were not statistically different among seasons (Figure 4; Kruskal-Wallis: $\mathrm{H}=2.704$; $\mathrm{gL}=3$; $p=0.4395)$. However, the largest daily home-range sizes were observed in autumn, $2002\left(35.70 \mathrm{~km}^{2}\right)$ and the largest mean daily home-range was observed also in autumn, $2002\left(10.26 \mathrm{~km}^{2}\right)$.

\section{Discussion}

The activities of the resident group of estuarine dolphins are restricted to the inside of Norte Bay, more specifically to its western part, while the use of the eastern part was not observed. Heterogeneous (non-random) use of space is common among other estuarine dolphin populations (Cremer, 2000; Bonin, 2001; Lodi, 2003) and also among other species of coastal dolphins, such as the bottlenose, Tursiops truncatus (Gubbins, 2002), and the Indo-Pacific humpback dolphin, Sousa chinensis (Karczmarski et al., 2000). The non-random distribution of the estuarine dolphin may reflect the heterogeneity of

Table 2. Seasonal group home-range and core area sizes of Sotalia guianensis using the minimum convex polygon (MCP) and kernel 50 and 95\% methods in Norte Bay.

\begin{tabular}{lcccr}
\hline Season & $\begin{array}{c}\text { kernel 95 } \\
\left(\mathbf{k m}^{2}\right)\end{array}$ & $\begin{array}{c}\text { kernel 50 } \\
\left(\mathbf{k m}^{2}\right)\end{array}$ & $\begin{array}{c}\text { kernel 50/95 } \\
\text { ratio } * \mathbf{1 0 0}\end{array}$ & $\begin{array}{r}\mathbf{M C P} \\
\left(\mathbf{k m}^{2}\right)\end{array}$ \\
\hline $\begin{array}{l}\text { Spring } \\
2001\end{array}$ & 8.32 & 0.73 & 8.77 & 9.80 \\
$\begin{array}{l}\text { Summer } \\
2002\end{array}$ & 8.42 & 0.74 & 8.79 & 12.94 \\
$\begin{array}{l}\text { Autumn } \\
2002\end{array}$ & 20.27 & 3.80 & 18.75 & 77.08 \\
$\begin{array}{l}\text { Winter } \\
2002\end{array}$ & 32.12 & 3.91 & 12.17 & 46.15 \\
\hline
\end{tabular}



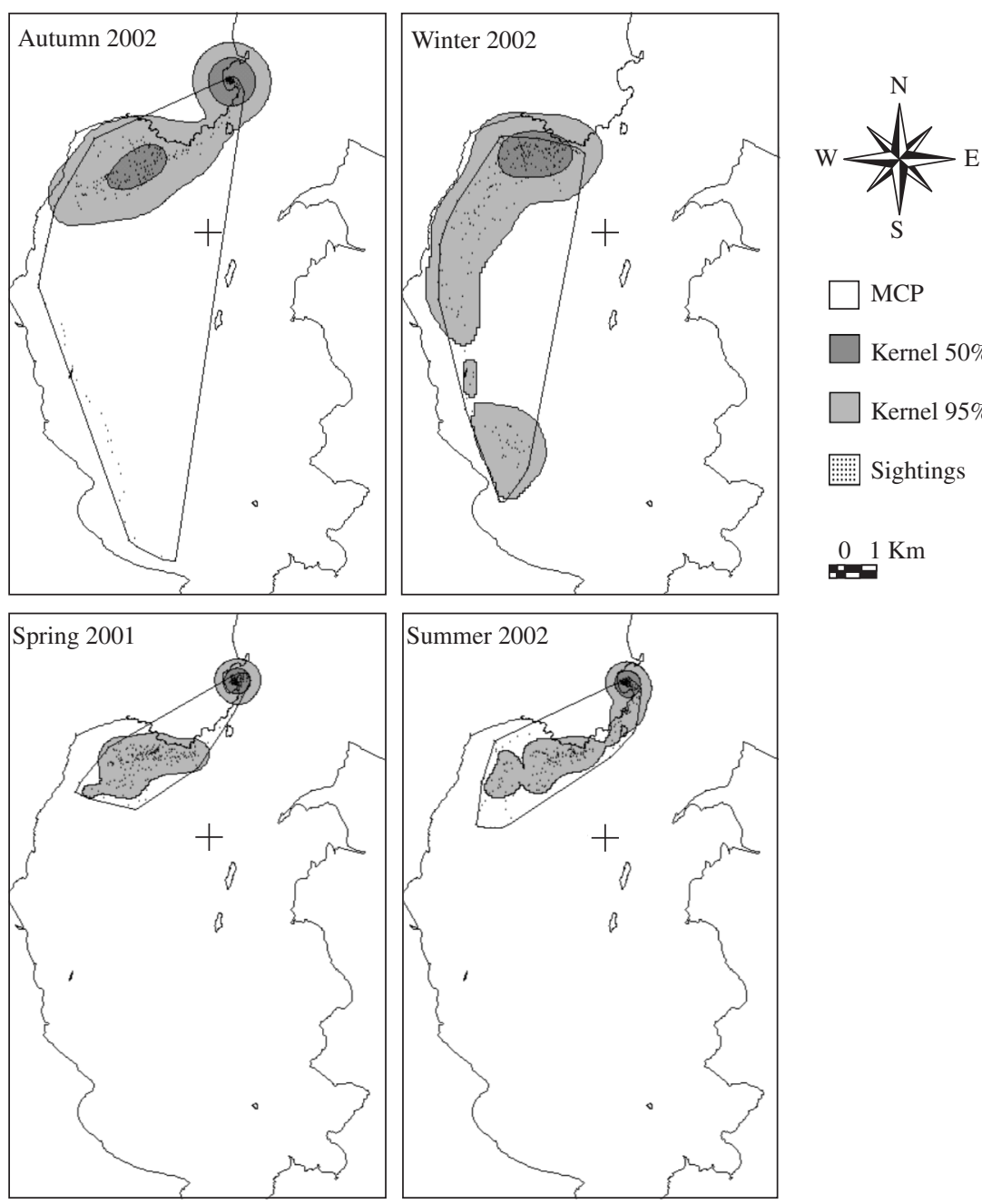

+ UTM reference point: $740000-6960000$

Figure 3. Comparison of seasonal group home-range of Sotalia guianensis using the minimum convex polygon and kernel methods (50 and 95\%) from spring, 2001 to winter, 2002 in Norte Bay.

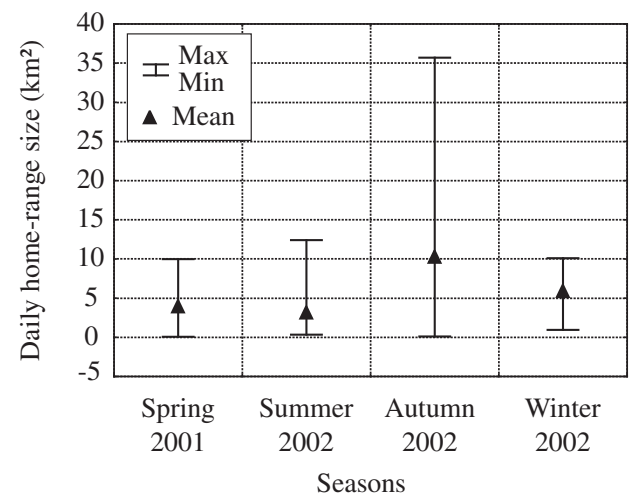

Figure 4. Variation of the mean, minimum and maximum daily home-range size of Sotalia guianensis in Norte Bay among different seasons. Differences not significant (Kruskal-Wallis, $\mathrm{p}=0.4395$ ). coastal habitats and its consequences on the distribution of prey and/or predators.

Another possible explanation for the heterogeneous use of Norte Bay by the estuarine dolphins may be the presence of the larger bottlenose dolphin. A spatial segregation, with little overlap, is observed when the distribution data of both species is plotted on a map (Flores, 2003; Daura-Jorge, 2003). Although this may be a prominent ecological phenomenon, more research is needed in order to identify the true causes of such a spatial relationship between these two species. One hypothesis is that the segregation is caused by a simple differential habitat selection, and each species has particular and distinct habitat preferences. However, this hypothesis is weakened by the observation of an aggressive interaction between the two species in the area (Wedekin et al., 2004). In spite of the very particular nature of these aggressive interactions, one possible cause of the spatial 
segregation is inter-specific territoriality (Brown and Orians, 1970). This last hypothesis should nevertheless be viewed with caution because individuals of different species may experience greater behavioural and morphological differences, making the spatial exclusion less probable (Brown and Orians, 1970).

The residence and site fidelity of the estuarine dolphins in Norte Bay were observed through previous individual photo-identification studies (Flores, 1999, 2003). In the present study, it was observed that this residency is spatially restricted to the waters within the bay. The social cohesion of the Norte Bay population also produces a spatial relationship which is highly clumped and aggregated, with extensive overlapping among individual home-ranges (Flores, 2003). The same spatially-strict residency was observed by Cremer (2000) in Babitonga Bay, 150 kilometres north, where the estuarine dolphin uses a well-defined area. Although individual movements in and out of Norte and Babitonga Bays were not observed, it is still possible that such events may occur. However, the fact that much observation has not detected such movements indicates that their frequencies are probably low.

The spatial use and residency patterns may be responses of habitat characteristics and behaviour strategies to cope with a varying environment. For the coastal estuarine dolphin, this pattern may be as variable as that of the bottlenose dolphin (Ballance, 1992), but the observed tendency is that estuarine dolphins are year-round residents (Geise, 1991; Cremer, 2000; Bonin, 2001; Lodi, 2003) and movements are probably restricted to a local scale, as analyzed in this work. In Guanabara Bay, for example, estuarine dolphins' movements in and out of the bay can be observed on a daily basis (Geise, 1991). In Norte Bay, the dolphins' movements also have a daily rhythm but are restricted to the inside of the bay (Daura-Jorge, 2003). The year-round residency strategy of estuarine dolphins is consistent with the use of highly productive coastal ecosystems, such as protected bays and estuaries (Borobia et al., 1991) and the generalist diet of the species (Borobia and Barros, 1989; Silva and Best, 1996). Migration or long-range dispersal and movements have never been recorded for the species.

The differences between the dolphins' distribution and the stranding localities indicate that dead dolphins' carcasses may drift for a considerable time before reaching land. Inferences of actual distribution from stranding data must be considered carefully, except in studies focusing on large spatial scale. Due to the widespread pattern of occurrence of strandings in relation to a restricted distribution, strategies to rescue dead animals' carcasses must be planned to involve the entire Norte Bay and not only the areas adjacent to the dolphins' distribution.

The size and areas comprised by the seasonal group home-range demonstrated a strong seasonal variation between the hot and cold seasons. The seasonal group home-range was smaller in the hot seasons and larger in the cold seasons. Based on the diet of the dolphins and on the seasonal variation of abundance of dominant prey types (especially fish from the Engraulidae Family), it has been hypothesized that the greater spatial requirements of the estuarine dolphins in the cold seasons were due to a lower abundance of food resources, whereas the opposite occurs in the summer (Daura-Jorge, 2003; Wedekin, 2003; Daura-Jorge et al., 2004). The negative relationship between the abundance of major food items and the size of the area used by individuals or groups has also been found in primates (Passamani and Rylands, 2000; Castro, 2003) and in one small cervid species (Tufto et al., 1996).

Some portions of the seasonal group home-range were very frequently used by the dolphins. The excessive use of certain areas may be related to high concentrations of prey, and similar excessive use has been identified in other areas where the estuarine dolphin has been studied (Oliveira et al., 1995; Cremer, 2000; Bonin, 2001; Lodi, 2003). These areas may be considered more important because of their higher frequency of use by the dolphins in comparison with other portions of the available habitat. For this reason, the core areas may be regarded as critical habitats for conservation (e.g. Ingram and Rogan, 2002; Karczmarski et al., 2000).

We noted that the core areas also varied seasonally. The spring and summer core area (Currais Bay) has been identified by Flores (1999). However, we also identified a distinct core area during the winter season (São Miguel Bay). In the autumn, dolphins used both Currais Bay and São Miguel Bay core areas. Moreover, dolphins frequently move in a predictable way from Currais Bay, where the group can be encountered first, to São Miguel Bay (Daura-Jorge, 2003).

Seasonal changes in the areas used have been noted in several odontocete species, such as T. truncatus (Shane, 1980; Irvine et al., 1981; Wilson et al., 1997), Lagenorhynchus obscurus (Würsig and Würsig, 1980), Cephalorhynchus hectori (Bejder and Dawson, 2001), S. chinensis (Karczmarski et al., 1999) and Orcinus orca (Nichol and Shackleton, 1996). In all the cases cited above, these changes have been attributed to changes in prey distribution and abundance, and indeed, fish stocks generally suffer great abundance changes in time and space (Laevastu and Hayes, 1989).

In our study, the size of the daily group home-range did not differ statistically among seasons, although the highest values were observed in the cold seasons. Similar results have been obtained with one rodent species in which the daily and seasonal home-range differed in size and shape (Spencer et al., 1990) and with primates where the daily home-range does not directly reflect the seasonal or long-term home-range (Crockett and Eisenberg, 1987). The cause of such a pattern may be a daily limit of energy expenditure that an animal is constrained by (Crockett and Eisenberg, 1987), but this interpretation must be viewed with caution because of the lower cost of moving in the water compared with moving on land.

The discrepancy between the legal limit of the Environment Protection Area of Anhatomirim and its natural boundaries (which correspond to the distribu- 
tion of the dolphins) has been discussed and analyzed more profoundly by Wedekin et al. (2002). The results presented here only emphasize that the design of this marine protected area does not meet its main objective of protecting the resident estuarine dolphin population.

The spatial patterns presented here for the estuarine dolphin have important implications for the management of the EPA of Anhatomirim. One of these implications is that the planning (especially zoning) may not be effective if it does not consider the seasonal variations of spatial use by the dolphins. Human disturbance may be greatly amplified in the critical habitats (core areas), thus requiring special legislation and control.

Acknowledgments - We would like to thank: CNPQ, Socioambiental Consultores Associados Ltda. and Mercury Motores Náuticos for financial support; Emygdio MonteiroFilho, Maurício Graipel and Tânia Castellani for their comments on an early version of the manuscript; an anonymous reviewer for his comments and suggestions which greatly improved the final manuscript; Roberto F. Costa together with a number of colleagues who helped with field work; Robert J. Warren for revising the English version.

\section{References}

BALLANCE, LT., 1992. Habitat use patterns and ranges of the bottlenose dolphin in the Gulf of California, Mexico. Mar. Mamm. Sci., vol. 8, no. 3, p. 262-274.

BEJDER, L. and DAWSON, S., 2001. Abundance, residency, and habitat utilization of Hector's dolphins (Cephalorhynchus hectori) in Porpoise Bay, New Zealand. New Zealand Journal of Marine and Freshwater Research, vol. 35, no. 2, p. 277-287.

BONIN, C., 2001. Utilização de hábitat pelo boto-cinza, Sotalia fluviatilis guianensis (Cetacea: Delphinidae), na porção norte do complexo estuarino da Baía de Paranaguá, PR. MSc. thesis. Universidade Federal do Paraná, Curitiba.

BOROBIA, M. and BARROS, N., 1989. Notes on the diet of marine Sotalia fluviatilis. Mar. Mamm. Sci., vol. 5, no. 4, p. 395-399.

BOROBIA, M., SICILIANO, S., LODI, L. and HOEK, W., 1991. Distribution of the South American Dolphin Sotalia fluviatilis. Can. J. Zool., vol. 69, p. 1025-1038.

BROWN, JL. and ORIANS, GH., 1970. Spacing patterns in mobile animals. Ann. Rev. Ecol. and Syst., vol. 1, p. 239-262.

BURT, WH., 1943. Territoriality and homse range concepts as applied to mammals. J. Mamm., vol. 24, no. 3, p. 346-352.

CASTRO, CSS., 2003. Tamanho da área de vida e padrão de uso do espaço em grupos de sagüis, Callithrix jacchus (Linnaeus) (Primates, Callitrichidae). Rev. Brasil. Zool., vol. 20, no. 1, p. $91-96$.

CERUTTI, RL., 1996. Contribuição ao conhecimento da poluição doméstica na Baía Norte, área da Grande Florianópolis, SC. MSc. thesis. Universidade Federal de Santa Catarina, Florianópolis.

CREMER, MJ., 2000. Ecologia e Conservação do Golfinho Sotalia fluviatilis guianensis (Cetacea: Delphinidae) na Baía de Babitonga, Litoral Norte de Santa Catarina. MSc. thesis. Universidade Federal de São Carlos, São Carlos.
CROCKETT, CM. and EISENBERG, JF., 1987. Howlers: Variations in Group Size and Demography. In Smuts, BB., Cheney, DL. Seyfarth, RM., Wrangham, RW. and Strushsaker, TT. (eds.), Primate societies. The University of Chicago Press, Chicago.

DAURA-JORGE, FG., 2003. Variação sazonal e diária dos estados comportamentais, padrões de movimentação e tamanho de grupo do boto-cinza Sotalia guianensis (Cetacea: Delphinidae) na Baía Norte da Ilha de Santa Catarina, SC, Brasil. B.S. monography. Universidade Federal de Santa Catarina, Florianópolis.

DAURA-JORGE, FG., WEDEKIN, LL. and SIMÕES-LOPES, PC., 2004. Variação sazonal na intensidade dos deslocamentos do boto-cinza, Sotalia guianensis (Cetacea: Delphinidae), na Baía Norte da Ilha de Santa Catarina. Biotemas, vol. 17, no. 1, p. 203-216.

FILHO, EM., MARTINS, RP. and FRANCO, D., 1997. Standing Wave Tide at Florianópolis Bay (Brazil) and its Influence on Bay Pollution. In Proceedings of the BORDOMER 97 - Coastal Environment Management and Conservation, Tomo 2, Bordeaux, France. p. 143-151.

FLORES, PAC., 1999. Preliminary results of a photoidentification study of the marine tucuxi, Sotalia fluviatilis, in Southern Brazil. Mar. Mamm. Sci., vol. 15, no. 3, p. 840-847.

FLORES, PAC., 2003. Ecology of the marine tucuxi dolphin (Sotalia fluviatilis) in southern Brazil. Ph.D. dissertation. Pontifícia Universidade Católica do Rio Grande do Sul, Porto Alegre.

GEISE, L., 1991. Sotalia guianensis (Cetacea: Delphinidae) population in the Guanabara Bay, Rio de Janeiro, Brazil. Mammalia, vol. 55, no. 3, p. 371-379.

GUBBINS, C., 2002. Use of home ranges by resident bottlenose dolphins (Tursiops truncatus) in a South Carolina estuary. J. Mamm., vol. 83, no. 1, p. 178-187.

HARRIS, S., CRESSWELL, W J., FORDE, PG., TREWHELLA, WJ., WOOLLARD, T. and WRAY, S., 1990. Home-range analysis using radio-tracking data - a review of problems and techniques particularly as applied to the study of mammals. Mammal, Rev., vol. 20, no. 2-3, p. 97-123.

HOOGE, PN. and EICHENLAUB, B., 1997. Animal Movement Extension to ArcView (version 1.1). Alaska Biological Science Centre, United States Geological Survey, Anchorage.

IBAMA/GTEMA, 2001. Mamíferos Aquáticos do Brasil: Plano de Ação. $2^{\mathrm{a}}$ edição. Edições IBAMA / MMA, Brasília, 79p.

INGRAM, SN. and ROGAN, E., 2002. Identifying critical areas and habitat preference of bottlenose dolphins Tursiops truncatus. Mar. Ecol. Prog. Ser., vol. 244, no. 4, p. 247-255.

IRVINE, AB., SCOTT, MD., WELLS, RS. and KAUFMANN, JH., 1981. Movements and activities of the Atlantic bottlenose dolphin, Tursiops truncatus, near Sarasota, Florida. Fish. Bull., vol. 79, no. 4, p. 671-688.

KARCZMARSKI, L., COCKCROFT, VG. and MCLACHLAN, A., 1999. Group size and seasonal pattern of occurrence of humpback dolphins Sousa chinensis in Algoa Bay, South Africa. South African Journal of Marine Science, vol. 21, p. 89-97.

KARCZMARSKI, L., COCKCROFT, VG. and MCLACHLAN, A., 2000. Habitat-use and preferences of Indo-Pacific Humpback dolphins Souza chinensis in Algoa Bay, South Africa. Mar. Mamm. Sci., vol. 16, no. 1, p. 65-79. 
LAEVASTU,T.andHAYES,ML.,1989.Fisheries Oceanography and Ecology. Fishing News Books, Farnham, 199p.

LEHNER, PN., 1996. Handbook of ethological methods. $2^{\text {nd }}$ edition. Cambridge University Press, Cambridge, 672p.

LODI, LF., 2003. Seleção e uso do hábitat pelo boto-cinza, Sotalia guianensis (Van Bénéden, 1864) (Cetacea, Delphinidae), na Baía de Paraty, Estado do Rio de Janeiro. Bioikos, vol. 17, no. $1-2$, p. $5-20$.

MONTEIRO-FILHO, ELA., MONTEIRO, LR. and REIS, SF., 2002. Skull shape and size divergence in dolphins of the genus Sotalia: a tridimensional morphometric analysis. J. Mamm., vol. 83 , no. 1, p. 125-134.

NICHOL, LM. and SHACKLETON, DM., 1996. Seasonal movements and foraging behaviour of northern resident killer whales (Orcinus orca) in relation to the inshore distribution of salmon (Oncorhynchus spp.) in British Columbia. Can. J. Zool., vol. 74, no. 6, p. 983-991.

OLIVEIRA, JA., ÁVILA, FJC., JÚNIOR, TTA., FURTADONETO, MAA. and MONTEIRO-NETO, C., 1995. Monitoramento do boto cinza, Sotalia fluviatilis (Cetacea: Delphinidae) em Fortaleza, Estado do Ceará, Brasil. Arquivo de Ciências do Mar, vol. 29, no. 1-2, p. 28-35.

PASSAMANI, M. and RYLANDS, AB., 2000. Home range of a Geoffroy's marmoset group, Callithrix geoffroyi (Primates, Callitrichidae) in south-eastern Brazil. Rev. Brasil. Biol., vol. 60 , no. 2 , p. $275-281$.

POWELL, RA., 2000. Animal Home Ranges and Territories and Home Range Estimators. In BOITANI, L. and FULLER, TK. (eds.), Research Techniques in Animal Ecology: Controversies and Consequences. Columbia University Press, New York..

REYNOLDS, TD. and LAUNDRE, JW., 1990. Time intervals for estimating pronghorn and coyote home ranges and daily movements. J. Wildl. Mgmt., vol. 54, no. 2, p. 316-322.

SHANE, SH., 1980. Occurrence, movements, and distribution of bottlenose dolphins, Tursiops truncatus, in southern Texas. Fish. Bull., vol. 78, no. 3, p. 593-601.

SHANE, SH., 1990. Behavior and Ecology of the Bottlenose Dolphin at Sanibel Island, Florida. In LEATHERWOOD, S. and REEVES, RR. (eds.) The Bottlenose Dolphin. Academic Press, San Diego.

SIEGEL, S., 1956. Nonparametric Statistics for the behavioral sciences. McGraw-Hill Book Company, New York, 312p.

SILVA, VM. and BEST, RC., 1996. Sotalia fluviatilis. Mammalian Species, vol. 527, p. 1-7.

SIMÕES-LOPES, PC., 1988. Ocorrência de uma população de Sotalia fluviatilis Gervais, 1853, (Cetacea, Delphinidae) no limite sul de sua distribuição, Santa Catarina, Brasil. Biotemas, vol. 1 , no. 1, p. 57-62.

SOLLA, SR., BONDURIANSKY, R. and BROOKS, R. 1999, Eliminating autocorrelation reduces biological relevance of home range estimates. J. Anim. Ecol., vol. 68, no. 2, p. 221-234.

SPENCER, SR., CAMERON, GN. and SWIHART, RK. 1990, Operationally defining home range: temporal dependence exhibited by hispid cotton rats. Ecology, vol. 71, no. 5, p. 1817-1822.

STACEY, PB., 1986. Group size and foraging efficiency in yellow baboons. Behav. Ecol. Sociobiol., vol. 18, no. 3, p. $175-187$.

SWIHART, RK. and SLADE, NA., 1985. Testing for independence of observations in animal movements. Ecology, vol. 66 , no. 4 , p. 1176-1184.

THOMPSON, WL., WHITE, GC. and GOWAN, C., 1998. Monitoring Vertebrate Populations. Academic Press, San Diego, 365p.

TUFTO, J., ANDERSEN, R. and LINELL, J., 1996. Habitat use and ecological correlates of home range size in a small cervid: the roe deer. J. Anim. Ecol., vol. 65, no. 6, p. 715-724.

WEDEKIN, LL., 2003. Padrões de uso espacial e conservação do boto-cinza, Sotalia guianensis (Cetacea: Delphinidae) na Baía Norte de Santa Catarina, Brasil. B. S. monography. Universidade Federal de Santa Catarina, Florianópolis.

WEDEKIN, LL., DAURA-JORGE, FG. and SIMÕES-LOPES, PC., 2002. Desenho de unidades de conservação marinhas com cetáceos: estudo do caso do boto-cinza, Sotalia guianensis, na Baía Norte de Santa Catarina, Sul do Brasil. In Proceedings of the III Congresso Brasileiro de Unidades de Conservação, Fortaleza, pp. 56-62.

WEDEKIN, LL., DAURA-JORGE, FG. and SIMÕES-LOPES, PC., 2004. An aggressive interaction between the bottlenose dolphin (Tursiops truncatus) and the estuarine dolphin (Sotalia guianensis) in southern Brazil. Aquat. Mamm., vol. 30, no. 3, p. 391-397.

WILSON, B., THOMPSON, PM. and HAMMOND, PS., 1997. Habitat use by bottlenose dolphins: seasonal distribution and stratified movement patterns in the Moray Firth, Scotland. $J$. Appl. Ecol., vol. 34, no. 6, p. 1365-1374.

WORTON, BJ., 1989. Kernel methods for estimating the utilization distribution in home-range studies. Ecology, vol. 70, no. 1 , p. 164-168.

WÜRSIG, B. and WÜRSIG, M., 1980. Behavior and ecology of the dusky dolphin, Lagenorhynchus obscurus, in the South Atlantic. Fish. Bull., vol. 77, no. 4, p. 871-890. 